\title{
Entrepreneurial Orientation and Performance of Hospitality Industry in Akure, Nigeria
}

\author{
Olowofeso, Edamisan* Ale, Olatide Aarinola \\ Department of Entrepreneurship, School of Management Technology, \\ The Federal University of Technology, Akure, Nigeria
}

\begin{abstract}
The main purpose of the study is to investigate the effect of entrepreneurial orientation-dimension (innovativeness, proactiveness, competitive aggressiveness, risk- taking and autonomy) on the performance of hospitality industry in Akure, Nigeria. The study adopts quantitative methods by using survey questionnaire structure in 5- point Likert scale. 122 copies of questionnaire were administrated to the 122 owners of hotels and guest houses in the study area, out of which 108 copies were retrieved for analysis using correlation and regression technique. From the result of correlation coefficient, innovation and competitive aggressiveness were positively and significantly with performance of hospitality industry at 0.01 significant level. The result of regression analysis shows an R-square of 0.426 , which indicated that $43 \%$ of change in firm performance was affected by independent variables. The results also indicates that three of the dimensions, namely innovativeness $(\beta=0.198, p-$ value $=0.000)$, proactiveness $(\beta=0.076 \mathrm{p}$ - value $=0.010)$ and competitive aggressiveness $(\beta=$ $0.191, \mathrm{p}$-value 0.000 ) were significantly and positively affect the performance of hospitality industry. Risktaking $(\beta=-0.095, p-$ value $=0.001)$ was significant but had negative effect on the performance of hospitality industry. However, autonomy $(\beta=-0.101, p-$ value $=0.091)$ was not have significant effect on the performance of the organisation. The study recommends that the three EO- dimensions (innovativeness, proactiveness and competitive aggressiveness that tends to be positive and significant influenced the performance of hospitality industry should be made the focal point of strategy for business growth and expansion.
\end{abstract}

Keywords: Entrepreneurial orientation, Hospitality industry, Performance, Akure, Nigeria

DOI: $10.7176 / \mathrm{EJBM} / 11-2-07$

\section{Introduction}

Hospitality industry is a service oriented business that can be found in several strategic locations of any city. The business renders service to guests or visitors from or within and outside their environment. The business is seen as the people business whose primary activities are the provision of accommodation, selling of food, beverage for consumption on the premises and provision of entertainment (Ofobruku, Kamoli \& Amagbkhen, 2012; Ofobruku, 2013). The hospitality sector enhances community development, creates new jobs, and provides a better quality of life for the residents. The contribution of the sector to Gross Domestic Product (GDP) is also significant as it amounting to over $10 \%$ (GDP) of any nation and employing huge numbers in the global workforce (Oyinbo, 2013). Due to the large number of hospitality businesses in Akure has forced the businesses into competing situations whereby those without the internal and external strengths are now phasing out of operations (Ofobruku \& Obia, 2012).

As a result of compaction in the marketplace, globalisation and influence of technology in recent years, innovation is considered as a necessity of every company (Tajeddini \& Trueman, 2008). At the same time, to achieve market success and sustain a competitive advantage, businesses need to exploit new opportunities (Berthon, McHulbert \& Pitt, 2004). Consequently, the past decade have witnessed great interest in the constructs of innovativeness and entrepreneurial organisation by scholars across disciplines (Hult, Hurley \& Knight, 2004). A wealth of thought over the years has developed evidence of pursuit of entrepreneurial orientation imperative aimed at successfully enhancing business performance (Tajeddini \& Trueman, 2008).

Empirical work related to services is still quite scarce in despite the fact that the service sector has become extremely large part of the modern economy and there are a large number of studies which have paid attention to service sectors (Steven \& Dimitriadis, 2005). Over the past few years, different scholars such as; MaydeuOlivares and Lado (2003); Ndungu (2014); Nyangau (2014) and Olaniran (2016) have tended to focus primarily on certain research streams concerning this issues. For instance, Maydeu-Olivares and Lado (2003) role of entrepreneurial orientation in insurance industry, Ndungu (2014) moderating role of entrepreneurial orientation on relationship between information security and firm performance in Kenya; Nyangau (2014), role of entrepreneurial leadership in growth of micro and small enterprises; Olaniran (2016) role of entrepreneurial orientation on performance of firms in Nigerian stock exchange. However, there is a lack of innovation research about hospitality industries (Ottenbacher \& Gnoth, 2005; Orfila-Sintes \& Mattsson 2009) and, more specifically in the developing nation like Nigeria; little knowledge exists regarding the effect of entrepreneurial orientation on the performance of the companies that provide services to the consumer, such as hotels and guest houses.

Thus, previous studies have tried to identify the factors that influences the performance of service business 
by focusing on the quality of service as a factor that satisfies customers' needs and improve organisational performance (Lee, Lee \& Yoo, 2000; Fodness \& Murray, 2007; Uelschy, Laroche, Eggert \& Bibdi, 2007; Chen \& Arttejo, 2008; Choi \& Mattila, 2008). However, study that investigated the effect of entrepreneurial orientation on service business are still few, despite the fact that entrepreneurial orientation has long been suggested as an essential attribute of high-performing firms (Lee \& Peterson, 2000). There is paucity of empirical documentation about the impact of entrepreneurial orientation on the performance of service business. Thus, the purpose of this study is to investigate the impact of entrepreneurial orientation on the performance of hospitality industry in Akure, Ondo State, Nigeria.

\section{Literature Review}

\subsection{Concept of Hospitality Business}

The word 'hospitality' originates from the latin word 'hospe' which imply host or guest and hospitium, which imply guest chamber, inn or quarter (Chon \& Sparrow, 2000). According to Ofobruku (2013), Hospitality industry in Nigeria was introduced by the colonial master in 1920 s by the establishment of catering guest houses and other catering guest houses across the country in the 1950s which marked the beginning of what turned out in the later years to form the genesis of formal hotel business in Nigeria. Hospitality business is seen as the commercial activities which offer consumers accommodation, means and drinks when out from home while promoting a welcome, warm friendly experience that benefits travelers (George, 2001). Rundell (2007) defined hospitality as friendly and generous behavior towards visitors and guests, intended to make them feel welcome: food, drink, room and entertainment given to customers a company or organisation. Cooper, Westlake and Shephard (1996) defines hospitality as a combination of physiological and psychological comfort within defined levels of services. The primary interesting elements is that of the social relationship fostered by the warm, friendly, welcoming courteous, open, generous behaviors of host creating the hospital social environment. This promotes the positive feeling of security and comfort created by physical structure, design, location of facilities, provisions of accommodation facilities to sleep, eat, relax and wash, together with the supply of beverage, service and entertainment.

\subsection{Entrepreneurial Orientation (EO) and Performance of firms}

Entrepreneurial orientation is described as the involvement of a firm to enter a new market (Lumpkin \& Dess, 1996; Lee \& Peterson, 2000). Avlonitis and Salavou (2007) posited EO constitutes an organisational phenomenon that reflects a managerial capability by which firms embark on proactive and aggressive initiatives to alter the competitive scene to their advantage. The concept of EO was compared to entrepreneurial management by Stevenson and Jarillo (1990) and the dimensions associated to it were originated from Miller's (1983). EO has evolved from, having three dimensions, namely: innovativeness; risk-taking and; pro-activeness (Covin \& Slevin, 1991) to five, with the other two known as competitive aggressiveness and autonomy (Lumpkin \& Dess 1996). Extensive studies have shown a significant influence of EO on performance of any firms (Keh, Nguyen \& Ng, 2007). Furthermore, it has also been confirmed by many previous study as a critical element to the success of small firms (Tzokas, Carter \& Kyriazopoulos, 2001; Zainol and Daud (2011); for examples international expansion (Javalgi \& Todd, 2011), financial performance (Hameed \& Ali, 2011), sales growth (Casillas \& Moreno, 2010) and employment growth (Madsen, 2007) of SMEs. However, some contradicting results have been obtained in studies performed by Soininen, Martikainen, Puumalainen \& Kylaheiko, (2012) in which they found EO as an individual construct did not positively relate to profitability.

The influence of EO on performance of firm in the private sector has been extensively carried out, but the effort to extend this EO-Performance relationship on hospitality industry is still low. As such, this study was conducted to shed lights on such issue. Although there were some researchers who deemed EO as a unique construct (Wiklund, 1999; Grand et al., 2011). Lumpkin and Dess (1960) have urged to view it has multidimensional construct because the dimension of EO may vary independently subject to the context of environment and organisation. Following Casillas and Moreno (2010), Hughes and Morgan (2007) and Li, Huang and Tsai (2009), this study regarded EO, has having multiple dimensions, which consist of innovativeness, pro-activeness, risk-taking, competitive aggressiveness and autonomy. The discussions below further explain the effects of these five dimensions on the performance of firms.

\subsection{Dimensions of entrepreneurial orientation}

The measurement dimension of EO has evolved from a single dimension to a multidimensional one. Lumpkin and Dess (1996) developed five dimensions that characterize the EO of a firm: innovativeness, proactiveness, risk- taking, competitive aggressiveness and autonomy.

Innovativeness refers to the tendency for enterprises to adopt and support creative processes, which may bring new products, new technologies, new services, new inventions, new tests, among others (Lumpkin \& Dess, 2001). Innovativenesss motivates enterprises to increase investment to carry out technology innovation activities 
such as new technology acquisition, new product development, among others; thus, it can improve enterprise technological innovation ability (Rauch, Wiklund, Lumpkin \& Frese, 2009). Moreover, innovativeness can promote enterprise reform and innovation, accelerate the flow and transformation of new knowledge and contribute to the generation of new knowledge and technology, which improves enterprise innovation performance (Lumpkin \& Dess, 2001).

Proactiveness refers to the tendency for enterprises to take the positive marketing strategy, proactive action, and leading strategy to introduce new products, new processes, new technologies, and new services in order to transcend the competitors. In order to gain the competitive advantage, proactive enterprises tend to take advantage of the market opportunities ahead of competitive advantage of the enterprise (Antoncis \& Hisrich, 2001) thus, enterprise with proactiveness tend to find new market opportunities more easily, and take quick action on these opportunities, and the bring innovative performance to enterprises (Rauch et al., 2009).

Risk-taking refers to the tendency for enterprises to take bold action in order to pursue high reward and it can be explained from two aspects of technology and market. In the technological aspect, risk- taking reflects the willingness of enterprises to invest resources for technological innovation strategies or projects with a high risk of failure and uncertainty and is closely related to entrepreneurial risk performances and attitudes towards new technologies (Wikluad \& Shepher, 2003). The spirit of adventure can promote an enterprise's innovation, create new rules, and enhance the competitive advantage of enterprise. Risk- taking helps an enterprise from an organisational atmosphere of tolerance and risk. It is also a way to encourage the experiment which speeds up the acquisition, learning, and absorbing of the new external technology, and ultimately improves the enterprise's technology innovation performance (Dewett, 2004). In the market aspect, it reflects the willingness and tendency of the enterprise to undertake the uncertainty risk, of entering a new market and is closely related to the risk performance of enterprises. Under this tendency, enterprises often act positively when they cannot predict the future market, and constantly seek, discover, and make use of new opportunities to create the first- mover advantage and get the benefits of innovation (Dewett, 2004).

Competitive aggressiveness is the intensity of the firm's to improve their position to outdo and overtake the competitors in the marker (Lumpkin \& Dess, 1996). It is characterized by a strong offensive posture directed at overcoming competitors and may be quite reactive as when a firm aggressively enters a market that a rival has identified (Lumpkin \& Dess, 1997).

Autonomy refers to an independent action of individual or teams in ensuring ideas and concepts are being carried out till completion (Lumpkin \& Dess, 1996). Autonomy gives employees the chance to perform effectively by being independent, self- directed, and creative.

\section{Methodology}

A survey research design was adopted in this study using survey questionnaire. 122 list of hospitality business was obtained from the Ondo State Ministry of culture and Tourism. A total of 122 copies of questionnaire were distributed to the owners of these organisations in the study area using a total enumeration (census) technique. However, only 108 copies of questionnaires were retrieved which resulting to 89 percent response rate. The respondents were the owners/ top management of the hospitality business due to their knowledge and expertise in terms of operation and direction of the business. The survey questionnaires which consists of close-ended questions were divided into two sections: Section A: background information of the firm, Section B: consists of questions measuring the five dimentions of EO and business performance using a 5-point Likert scale. In this study, the independent variables (EO) are divided into five dimensions of EO represented by (i) innovativeness, (ii) proactiveness, (iii) risk- taking, (iv) competitive aggressiveness and (v) autonomy in which the respondents has to indicate the extent to which the items represent their firm's strategy, while the measurement adopted for performance of hospitality business were based on growth and profitability which were based from previous study (Balan \& Lindsay, 2010). This study uses Statistical Package for Social Sciences (SPSS) 23.0 to analyze the data obtained from the sample of population. The data analysis technique consists of frequency distribution, correlation and regression analysis.

\section{Results and Discussion}

\subsection{Findings and discussions of Descriptive analysis}

The information on the characteristics of the respondents in this study is presented in Table 1 . The results indicated that about $59(54.6 \%)$ of the respondents are with the active age bracket of 41-50 while the rest were either below 40 years or above 50 years. The results also reveal that $86(79.6 \%)$ of the respondents are male while the remaining $22(20.4 \%)$ are female. In term of the qualifications, more than half of the respondents have HND /BSc with 68(63\%). This was follow by those with OND/ NCE with 31(28.7\%), and MSc and above have $7(6.5 \%)$ while those with less than OND/NCE have $2(1.9 \%)$. This indicated that majority of the respondents have a high academic qualification and affect the degree of adoption of EO demotion in the organisation. This may be attributed to the educational level and skills acquired that has translated to the enterprises performance. 
With respect to level of experience those that has being in the business between 1-5 years are $16.7 \%$, between 6 10 years are $62.0 \%$, between $11-15$ years $=10.2 \%$, and above 15 years are $11.1 \%$. With this result it shows that majority of the respondents have being into the business for good numbers of years therefore, are likely to provide reliable information that can yield better results about the organisation.

Table 1: Demographic characteristics of the respondents

\begin{tabular}{lll}
\hline Variable & Frequency & Percent \\
\hline Age & 2 & 1.9 \\
Less than 30 years & 5 & 6.6 \\
30-40 years & 59 & 54.6 \\
41-50 years & 42 & 38.9 \\
Above 50 years & & \\
Gender & 86 & 79.6 \\
Male & 22 & 20.4 \\
Female & & \\
Qualification & 2 & $1-9$ \\
Less than OND/NCE & 31 & 28.7 \\
OND/NCE & 68 & 63.0 \\
HND/BSc & 7 & 6.5 \\
MSc and above & & \\
Experience in the business & 18 & 16.7 \\
$1-5$ years & 67 & 62.0 \\
6-10 years & 11 & 10.2 \\
$11-15$ years & 12 & 11.1 \\
Above 15 years & & \\
\hline Source: Field Survey, 2018 & & \\
\hline
\end{tabular}

Source: Field Survey, 2018

Mean score and correlation analysis

Table 2 summarises the information on means and standard deviations (S.D.) of variables and correlations between the variables. The mean values and standard deviations of the independent and dependent variables are; Innovativeness recorded the highest mean value at 3.95 (S.D.=0.617), Proactiveness 1.37 (S.D. $=0.827$ ), Competitive aggressiveness 3.92 (S.D. = 0.598), Risk- taking 3.56 (S.D. = 0.857), and Autonomy 3.93 (S.D. = 0.487 ) while depended variable performances was 1.08 with S.D. of 0.278 . The findings corroborated with the study of Dess and Lumpkin (2005) that innovativeness was of high importance because as the market change in a rapid pace, maintaining competitive advantage and innovativeness is crucial as it can be a source of significant progress and growth for a firm. The correlation of the variables was also carry out to identify the strategy and direction of relationship between two variables. Pearson product- moment correlation coefficient (r) was determined, In terms of relationship between independent and dependent variables, two of the independent variables - Innovativeness $(r=0.459)$ and Competitive aggressiveness $(r=0.493)$ were found to be statistically significant with dependent variable at 0.01 significant level. (See table 2 )

Table 2: Descriptive Statistics and Correlations for Entrepreneurial Orientation Variables

\begin{tabular}{lllllllll}
\hline Variables & Mean & S.D & 1 & 2 & 3 & 4 & 5 \\
\hline Innovativeness & 3.95 & .617 & 1 & & & & \\
Proactiveness & 1.37 & .827 & $-.369^{* *}$ & 1 & & & & \\
Competitive aggressiveness & 3.92 & .598 & $.597^{* *}$ & -.013 & 1 & & & \\
Risk- taking & 3.56 & .857 & .121 & $.203^{*}$ & $.348^{* *}$ & 1 & & \\
Autonomy & 3.93 & .487 & $.610^{* *}$ & $-.163^{*}$ & $.428^{* *}$ & $392^{* *}$ & 1 & \\
Performance & 1.08 & .278 & $.459^{* *}$ & .027 & $.493^{* *}$ & .121 & .115 & 1 \\
\hline
\end{tabular}

** Correlation is significant at the 0.01 level (2-tailed)

* Correlation is significant at the 0.05 level (2-tailed)

Source: Field Survey, 2018

\subsection{Multiple regression analysis of the variables.}

Multiple regression analysis was considered as appropriate in this study because more than one independent variable explained the variance in dependent variable. From the table 3 , three of the independent variablesinnovativeness, proactiveness and competitive aggressiveness are positively correlation with the dependent variable. This shows that an increase in the presence of these variables will lead to increase in the performance of the hospitality industry vis-à-vis. On the other hand, the negative sign of the independent variable- risk- taking and autonomy in the regression equation indicates that the presence of a unit increase in these two variables will have a reducing effect on the performance of the depended variable. Thus the equation of this model is given as: $\mathrm{Y}=\mathrm{f}\left(\mathrm{X}_{1}+\mathrm{X}_{2}+\mathrm{X}_{3}+\mathrm{X}_{4}+\mathrm{X}_{5}\right)$ 
$\mathrm{Y}=\beta_{O}+\beta_{1}\left(\mathrm{X}_{1}\right)+\beta_{2}\left(\mathrm{X}_{2}\right)+\beta_{3}\left(\mathrm{X}_{3}\right)+\beta_{4}\left(\mathrm{X}_{4}\right)+\beta_{5}\left(\mathrm{X}_{5}\right)+\ell i$

Hence the regression model is given as:

$\mathrm{Y}=0.198+0.076+0.191+0.095-0.101$

The results of regression analysis also revealed that data in this study fits the model well, it was confirmed by the F-statistics of 15.111 and significant at 0.000 . Thus, the relationship between EO and performances was statistically significant. The R- square obtained was 0.426 and adjusted R-square was 0.397 . This indicates that $43 \%$ of change in firm performances was affected by EO dimensions used in the study. The result also showed that there was statistical significant relationship between innovativeness $(\beta=0.198, \mathrm{p}-$ value $=0.000)$, Proactiveness $(\beta=0.076, p-$ value $=0.010)$, Competitive aggressiveness $(\beta=0.191, p-$ value $=0.000)$, Risktaking $(\beta=-0.095, p-$ value $=0.001)$ and performance of hospitality industry. There was no statistical significant relationship between autonomy $(\beta=-0.101, \mathrm{p}-$ value $=.091)$ and dependent variable.

Table 3: Multiple Regression Results

\begin{tabular}{|c|c|c|c|c|}
\hline \multirow[t]{2}{*}{ Model } & \multicolumn{2}{|c|}{ Unstandardized Coefficients } & \multirow[b]{2}{*}{ t- value } & \multirow[b]{2}{*}{ P-value } \\
\hline & B & Std. Error & & \\
\hline (Constat) & .185 & .196 & .946 & .347 \\
\hline Innovativenes & .198 & .055 & 3.633 & .000 \\
\hline Proactiveness & .076 & .029 & 2.633 & .010 \\
\hline \multicolumn{5}{|l|}{ Competitive } \\
\hline Aggressiveness & .191 & .047 & 4.021 & .000 \\
\hline Risk- taking & -.095 & .029 & -3.285 & .001 \\
\hline Autonomy & -.101 & .059 & -1.708 & .091 \\
\hline
\end{tabular}

R- Square $=0.426$

Adjusted R- Square $=0.397$

Standarded error $=0.216$

F- value $=15.111$

Source: Field survey, 2018

\subsection{Discussions}

From the statistical analysis performed, the study found that dimensions of EO have an impact on the performance of hospitality industry. In particular, among the five EO dimentiond analyzes, innovation play the most important role. Innovativeness has been evidenced by Hult et al., (2004), Hughes and Morgan (2007), Casillas and Moreno (2010), Hameed and Ali (2011) and Soininen (2012), as an important determinant of firms performance. Similar to the previous studies, this study also found such a result and further confirmed the findings of Dess and Lumpkin (2005), Rahman and Shariff (2009). Proactiveness was proven to significantly affect the performance of hospitality industry. This could be referred by the increasing quality and ability of the top- management in the forward- looking and seeking new opportunities. Competitive aggressiveness was also identified as one of the important factor, which was in contrast to Dess and Lumpkin (2005), Casillas and Moreno (2010); Hughes and Morgan (2007). As mentioned by Lumpkin and Dess (1996), this dimension plays a vital role in ensuring the firm to outperform the other rivals in the industry. The findings agree with those in Oni (2012) whose study concluded that the enterprises performance was a function of a wider based entrepreneurial pro-activeness. The competitive condition has definitely caused the hospitality industry to aggressively and intensely seek way to sustain in the industry. Risk- taking also emerged as one of important EO dimension which include influenced the performance of hospitality industry. The findings agreed with those in Dess and Lumpkin (2005) who found that firms with an EO often engage in risky activities, such as high leveraging and large resource commitments in the desire of gaining high returns by pursuing opportunities in the market. The finding also supported the position of Hameed and Ali (2011) and Soininen et al., (2012) in which assuming risk is related to firm's performance. The study found that majority of the hospitality industry are owned either by government and other top governmental functionary, it is therefore competitively easy for them to obtain the necessary resources for making investment whenever they identified new opportunities. This has definitely resulted in bold and brave decisions in marking investments by the top management hospitality industry. This study also found that there is no significant relationship between autonomy and performance of hospitality industry. The study was in contradiction with Csillas and Moreno (2010) and Hughes and Morgan (2007).

\subsection{Conclusion and recommendations}

This study was carried out with the aim to examine the five dimensions in EO as conceptualized by Lumpkin and Diss (1996) on the performance of hospitality industry. Statistical test revealed that three of five dimensions in EO, namely innovativeness, proactiveness and competitive aggressiveness significantly and positively influenced the performance of hospitality industry. Risk-taking was significant but negatively influenced the 
performance of hospital industry. However, autonomy was not identified as significant factors which influence the performance of the organisation when multiple regression analysis was conducted. Innovativeness was identified as the most important factor influencing the performance of hospitality industry, followed by competitive aggressiveness, proactiveness and finally risk- taking. The study recommends that the three EOdimensions that tend to be positive and significant effect on performances of hospital industry should be made the focal point of strategy for business expansion.

\section{References}

Antoncic, B. \& Hisrich, R. D. (2001). Intrapreneurship: Construct refinement and cross-ultural validation, Journal of Business Venturing, 16(5), 495-527.

Avlonitis, G. J., \& Salavou, H. E. (2007). Entrepreneurial orientation of SMEs, product innovativeness, and performance. Journal of Business Research, 60(5), 566-575.

Balan, P., \& Lindsay, N. (2010). Innovation capability, Entrepreneurial orientation and performance in Australian hotels: An empirical study. Cooperative Research Centre for Sustainable Tourism.

Berthon, P., MacHulbert, J., \& Pitt, L. (2004). Innovation or customer orientation? An empirical investigation. European Journal of Marketing, 38(9/10), 1065-1090.

Casillas, J. C., \& Moreno, A. M. (2010). The relationship between entrepreneurial orientation and growth. The moderating role of family involvement. Entrepreneurship \& Regional Development, 22(3-4), 265-291

Chen, G. H., \& Arttejo B. A. (2008). Service quality and customer satisfaction measurement of mobile valueadded services: a conceptual view. International Journal Mobile Commerce, 6(2), 165-176

Choi, S., \& Mattila, A. S. (2008). Perceived controllability and service expectations: influences on customer reactions following service failure. Journal of Business Research, 61(1), 24-30.

Chon, K., \& Sparrowe, R. T. (2000). Welcome to Hospitality: An introduction, Second edition. New York: Thomson Learning

Cooper, C., Westlake, J., \& Shephard, R. (1996). Educating the Educator in Tourism Madrid, Spain. Published by World Tourism Organisation.

Covin, J. G., \& Slevin, D. P. (1991). A Conceptual Model of Entrepreneurship as Firm Behavior. Entrepreneurship Theory and Practice. 16, 7-25.

Covin, J., Slevin, D. (1989). Strategic management of small firms in hostile and benign environments. Strategic Management Journal, 10, 75-87.

Fodness, D., \& Murray, B. (2007). Passenger's expectation of airport service quality. Journal Service Marketing, 21(7), 492-506.

George, R. (2001). Marketing South African Tourism and Hospitality. Cape Town. South Africa: Oxford University press.

Grande, J., Madsen, E. L., \& Borch, O. J. (2011). The relationship between resources, entrepreneurial orientation and performance in farm-based ventures. Entrepreneurship \& Regional Development, 23(3-4), 89-111.

Hameed, I., \& Ali, B. (2011). Impact of entrepreneurial orientation, entrepreneurial management and environmental dynamism on firm's financial performance. Journal of Economics and Behavioral Studies, $3(2), 101-114$.

Hollenstein, H. (2000) Innovation modes in the Swiss service sector: a cluster analysis based on firm-level data. In: 3rd Workshop of the "Focus Group on Innovative Firms and Networks" OECD Rome: Swiss Federal Institute of Technology Zurich: OECD-Project on "National Innovation Systems"

Hughes, M., \& Morgan, R. E. (2007). Deconstructing the relationship between entrepreneurial orientation and business performance at the embryonic stage of firm growth. Industrial Marketing Management, 36, 651661.

Hult, G. T. M., Hurleyb, R. F., \& Knight, G. A. (2004). Innovativeness: Its antecedents and impact on business performance. Industrial Marketing Management, 33, 429-438.

Javalgi, R. G., \& Todd, P. R. (2011). Entrepreneurial orientation, management commitment, and human capital. The internationalisation of SMEs in India. Journal of Business Research, 64(9), 1004-1010.

Keh, H. T., Nguyen, T. T. M., \& Ng, H. P. (2007). The Effects of Entrepreneurial Orientation and Marketing Information on the Performance of SMEs. Journal of Business Venturing. 22(4), 592-611.

Lee, C., Lee, K., \& Pennings, J. (2001). Internal Capabilities, External Networks, and Performance: A Study on Technology- based Ventures. Strategic Management Journal. 22, (6-7), 615-640.

Lee, H., Lee, Y., \& Yoo, D. (2000). The determinant of perceived service quality and its relationship with satisfaction. Journal Service Marketing 14(3), 217-231

Lee, S. M., \& Peterson, S. J. (2000). Culture, Entrepreneurial Orientation, and Global Competitiveness. Journal of World Business. 35 (4), 401.

Li, P. C., \& Evans, K. R. (2012). Effects of interaction and entrepreneurial orientation on organisational performance. Insights into market driven and market driving. Industrial Marketing Management, 41, 1019- 
1034.

Li, Y. H., Huang, J. W., \& Tsai, M. T. (2009). Entrepreneurial orientation and firm performance: The role of knowledge creation process. Industrial Marketing Management, 38, 440-449.

Lumpkin, G. T., \& Dess, G. G. (1996). Clarifying the entrepreneurial orientation construct and linking it to performance. Academic Management Review 21(1),135-172

Lumpkin, G. T., \& Dess, G. G. (2001). Linking Two Dimensions of EO to Firm Performance: The Moderating Role of Environment and Industry Life Cycle. Journal Business Venturing, 16(5), 429- 451.

Lumpkin, G., \& Dess, G. (1997). Proactiveness Versus Competitive Aggressiveness: Teasing Apart Key Dimensions of an Entrepreneurial Orientation. In P. D. Reynolds, W. D.

Madsen, E. L. (2007). The Significance of Sustained Entrepreneurial Orientation on Performance of Firms -A Longitudinal Analysis. Entrepreneurship \& Regional Development, 19(2), 185-204

Maydeu-Olivares, A., \& Lado, N. (2003). Market orientation and business economic performance: a mediated model. International Journal of Service Industry Management, 14(3), 284-309.

Miller, D. (1983). The correlates of entrepreneurship in three types of firms. Management Science, 29(7), 770791.

Morgan, R. E. \& Strong, C. A. (2003). Business Performance and Dimensions of Strategic Orientation. Journal of Business Research, 56(3), $163-176$.

Ndung'u, S. I. (2014). Moderating role of entrepreneurial orientation on the relationship between information security management and firm performance in Kenya. A Thesis Submitted in Partial Fulfilment for the Award of the Degree of Doctor of Philosophy in Entrepreneurship in the Jomo Kenyatta University of Agriculture and Technology

Nyangau, S. P. (2014). The influence of entrepreneurship on the growth of micro and small enterprises in Thika Town, Kenya. International Journal of Business, Humanities and Technology 4(2), 82-87.

Ofobruku, S. A., \& Obia, E. (2012). Quality Assurance In The Hospitality Industry: Nigeria Experirence. HATMAN Journal of Hospitality and Tourism, 2(1), 118-124.

Ofobruku, S. A. (2013). Assessment of leadership style among hospitality business In Abuja. Arabian Journal of Business and Management Review (OMAN Chapter) 2(6).

Ofobruku, S. A., Kamoli, M. K., \& Amagbakhen, O. R. (2012). Geographical information system technology as a decision support for hospitality management. European Scientific Journal, 8(23), 38-64.

Olaniran, O. (2016). Role of entrepreneurial orientation on performance of firms in the Nigerian stock exchange . Ph.D thesis Submitted in partial fulfilment for the degree of Doctor of Philosophy in Entrepreneurship in the Jomo Kenyatta University of Agriculture and Technology.

Oni, O. E. (2012). Relevance of entrepreneurial pro activeness on business performance: Nigerian Companies Experience. Kuwait Chapter of Arabian Journal of Business and Management Review 1(6)

Orfila-Sintes, F., \& Mattsson, J. (2009). Innovation behaviour in the hotel industry. The International Journal of Management Science, 37(9), 380-394.

Ottenbacher, M., \& Gnoth, J. (2005). How to develop successful hospitality innovation. Cornell Hotel and Restaurant Administration Quarterly 46(2), 205-222.

Oyibo, E. O. (2013). Hospitality industry and economic development in Nigeria; An investigative approach. Unpolished Master Thesis Department of Management, Faculty of Business Administration, University of Nigeria, Enugu Campus

Rahman, B. A., \& Shariff, M. N. M. (2009). Knowledge-based Malaysian GLC: Are they more innovative and performing much better? Malaysian Management Journal, 13(1\&2), 11-19.

Rauch, A., Wiklund, J., Lumpkin, G. T. \& Frese, M. (2009). EO and Business Performance: An Assessment of Past Research and Suggestions for the Future. Entrepreneurship Theory and Practice. 33, 761- 787.

Rundell, M. (2007). Macmillan English Dictionary For Advanced Learners. U. K. Macmillan Press. Arabian Journal of Business and Management Review (OMAN Chapter) 2(6)

Soininen, J., Martikainen, M., Puumalainen, K. \& Kyläheiko, K. (2012). Entrepreneurial orientation: Growth and profitability of Finnish small- and medium-sized enterprises. International Journal of Production Economics, 140, 614-621.

Soininen, J., Puumalainen, K., Sjögrén, H., \& Syrjä, P. (2012). The impact of global economic crisis on SMEs. Does entrepreneurial orientation matter? Management Research Review, 35(10), 927-944.

Stevens, E., \& Dimitriadis, S. (2005). Managingthe newservice developmentprocess: towards a systemic model. European Journal of Marketing, 39(1/2), 175-198.

Stevenson, H. H., \& Jarillo, J. C. (1990). A paradigm of entrepreneurship: Entrepreneurial management. Strategic Management Journal, 11, 17-27.

Tajeddini, K., \& Trueman, M. (2008). The potential for innovativeness: a tale of the Swiss watch industry. Journal of Marketing Management, 24(1-2), 169-184.

Tzokas, N., Carter, S., \& Kyriazopoulos, P. (2001). Marketing and entrepreneurial orientation in small firms. 
Enterprise and Innovation Management Studies, 2(1), 19-33.

Uelschy, L. C., Laroche, M., Eggert, A., Bibdi, U. (2007). Service quality and satisfaction: an international comparison of professional service perceptions. J Serv Mark 21(6), 410-423.

Wiklund, J. (1999). The Sustainability of the Entrepreneurial Orientation-performance Relationship. Entrepreneurship Theory and Practice, 24(1), 37-48.

Wiklund, J., \& Shepherd, D. (2005). Entrepreneurial Orientation and Small Business Performance: A Configurational Approach. Journal of Business Venturin. 20, 71-91

Zainol, F. A., \& Ayadurai, S. (2011). Entrepreneurial Orientation and Firm Performance: The Role of Personality Traits in Malay Family Firms in Malaysia. International Journal of Business and Social Science, 2(1), 59-72. 